\title{
HERITAGE TRAILS THROUGH DOLENJSKA AND BELA KRAJINA IN SLOVENIA - A MULTI-STAKEHOLDER APPROACH TO TOURISM DEVELOPMENT
}

Marko Koščak, Faculty of Tourism, Brežice, Slovenia

\begin{abstract}
One of the crucial methodologies for growing and developing a level of tourism which is sustainable and enhances the totality of local and regional environments is a multi-stakeholder approach to tourism development. In this paper, we present the case of the "Heritage trails through Dolenjska and Bela krajina in SE Slovenia" in which sustainable rural development (we take this to include cultural \& heritage, vinicultural \& gastronomic, as well as ecological tourism) is one of the key elements of the integral mix of business economy, viz. development of the region in the SE of Slovenia. The integral approach showed from the very beginning of project activities, within the Novo Mesto chamber of commerce, its long-time implementation until the present, as one of the key products within the tourist destination of Dolenjska, Bela Krajina and Kočevsko-Ribniška. It takes an integrated approach in terms of start-up, implementation and development and is supported by and benefits from the notion of a core of multiple stakeholders.
\end{abstract}

Key words: Multi-stakeholder approach \& partnership, Integrated project Heritage Trail Dolenjska \& Bela krajina, Slovenia, Sustainable tourism

\section{PUTEVIMA BAŠTINE DOLENJSKE I BELE KRAJINE, SLOVENIJA - TURISTIČKI RAZVOJ I MULTI- -STEJKHOLDERSKI PRISTUP}

Sažetak

Jedan od ključnih metodoloških pristupa za razvoj održivog turizma, odnosno podizanje razine i njegove efikasnosti, kako na lokalnoj, tako i na regionalnoj razini, je tkzv. multi-dionički pristup. U ovom radu želimo prezentirati primer dobre prakse "Putevima baštine Dolenjske i Bele krajine" u Sloveniji, gde je održivi ruralni razvoj i razvoj turizma (u kontekstu održivosti mislimo na kulturne, baštinske, enološke, gastronomske i slične aspekte) jedan od ključnih elemenata integralnog privrednog miksa odnosno razvoja regije na JI Slovenije. Integralni pristup odražavao se od samog početka izvođenja aktivnosti na projektu, u okviru Privredne komore Novo mesto, preko njegove dugogodišnje implementacije, do današnjeg trenutka, kao jednog od nosećih produkata u okviru turističke destinacije Dolenjska, Bela krajina i Kočevsko - ribniška. U kontekstu integralnosti osigurana je i podrška sa strane brojnih stejkholdera, među kojima su bili brojni od njih - kako nosioci, tako i korisnici učinka i rezultata projektnih aktivnosti. 
Ključne reči: multi-stejkolderski pristup \& partnerstvo, integralni projekt Putevima baštine Dolenjske \& Bele krajine, Slovenija, održivi turizam

TIMS Acta (2016) 10, 109-118

\section{Introduction}

Clearly the model as demonstrated in the Case Study utilised in this paper, has a very precise local/ regional orientation. The Heritage Trail of Dolenjska \& Bela krajina Case Study has a rural base and is profoundly affected by the necessity to attract tourism inputs without damaging the sensitivities of the rural environment. It also has a strong multi-stakeholder approach which in many ways illustrates the impact in EU-funded programmes of the concept of subsidiarity (The principle of subsidiarity is defined in Article 5 of the Treaty establishing the European Union and was intended to ensure that decisions are taken as closely as possible to the citizen and that constant checks are made as to whether action at supranational level is justified in the light of the possibilities available at national, regional or local level. The Edinburgh European Council of December 1992 issued a declaration on the principle of subsidiarity, which lays down the rules for its application (European Parliament, 2007), aiming at seamless connectivity between EU supranational policy and funding, member state objectives in macro-economic harmonisation and stabilities and local micro-economic needs.

It is a paradox that the decade of the 1960's - which saw the emergence of modern sustainable tourism, through the global movement for resource conservation and the limiting of development, also gave rise to a destructive counter-phenomenon! That counter-problem was the explosive rise in air-based international tourism, given added impetus as the result of the deregulation of airline routes in the European economic space. This revolution in low cost and accessible air transport which grew exponentially in the 1990's with the emergence of low-cost budget carriers has become damaging to the environment and culture of many tourist destinationregions. It has taken 40 years to respond effectively to this demanding global process, and to start to achieve sustainable rural regional tourism products and realities.

The rural case-study presented is one of a region in Slovenia along the border with Croatia, where a track of a fifteen year process was evidenced, from a preliminary idea - to the operational reality of sustainable international tourism in a strategically-located destination-region.

\section{Thesis, research \& methodological platforms}

Within the overall concept of socially, economically, and environmentally sustainable tourism, it is evident that European legislators are now greatly concerned to ensure that tourism is sustainable in economic, social, territorial, environmental and cultural terms. This takes cognisance of the fact that sustainably developed tourism is required to offer local economies (especially in disadvantaged regions) a long-term source of revenue, help in promoting stable employment structures, whilst at the same time safeguarding and enhancing the cultural, historical, landscape and environmental heritage.

Important future elements, in the light of the focus of this case study presented bellow, being on the Heritage trail model, are the EU-wide initiatives now in progress that seek to enhance the common cultural heritage, through the creation of a European heritage label. Cultural heritage, as we will see in the case study, also includes the protection of traditional culture, and in particular endangered folk arts, crafts, trades and knowledge. A further key element, related to the variety of stakeholders in sustainable tourism development, is the role of SME's and particularly of micro- and smallersized enterprises. EU institutions share a common view that SME's/MSE's should have greater involvement in tourism-related entrepreneurship and that possibilities for simplifying procedures to obtain financial support should be found.

Another important element is to study the impacts on tourism upon host communities, as well as upon host cultures. "Culture" (Tylor, 1871) was defined as "culture or civilisation, taken in its wide ethnographic sense, is that complex whole which includes knowledge beliefs, arts, morals, law, customs, and any other capabilities and habits acquired by man as a member of society." 
Malinowski (Malinowski, 1931) gave a more universal and less anthropocentric definition, namely "a culture is functioning, active, efficient, well-organised unity, which must be analysed into component institutions in relation to one another, and in relation to the environment, manmade as well as natural." In the report (Jones \& Travis, 1983 ) on Wales in 1983, the word 'culture' was taken to mean: "the system of values, beliefs, behaviours, morals, and other social phenomena shared by a group of people, based on their common experience of life, language and history."

In order to address these important components of sustainable tourism development detailed carrying capacity study was part of the project activities. Carrying capacity can be defined as "the maximum number of people who can use a site without an unacceptable alteration in the physical environment and without an unacceptable decline in the quality of the experience gained by visitors" (Mathieson \& Wall, 1982).

The factors that need to be considered are:

* Physical impact of tourists

* Ecological impact of tourists

* Perceptions of overcrowding on tourists.

* Cultural and social impact on local people.

The Heritage Trail is intended to be sustainable:

i. commercially successful (and therefore profitable)

ii. composed of local, small-scale enterprises - integrated into the local economy and contributing to "locally defined social, economic, environmental and cultural needs and objectives."

iii. respectful of the environment and designed to minimise environmental impacts through the use of existing structures and appropriate technology.

iv. be locally defined, owned, planned, and controlled.

The carrying capacity study is central to meeting these objectives, necessary in order to identify environmentally and culturally sensitive areas and ensuring that the Heritage Trail(s) are sustainable.
The purpose of the carrying capacity assessment is to ensure that the tourists and day visitors attracted to the Heritage Trail sites will not have a deleterious impact on the cultural or natural sites; that overcrowding will not result in visitor dissatisfaction and that local people will not feel antagonistic towards their "guests". This is essential if tourism is to contribute to the conservation of cultural and natural heritage though the realisation of economic value and raising awareness of, and commitment to, the local patrimony.

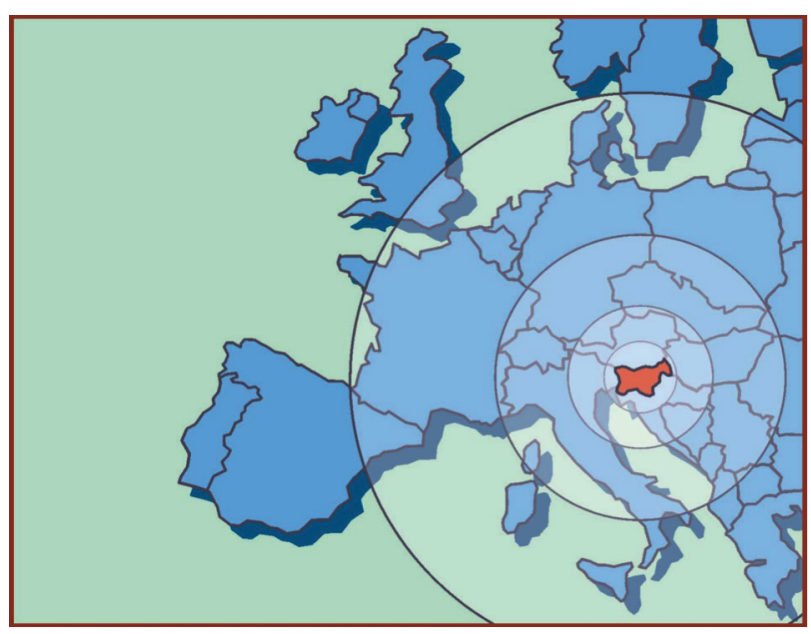

Figure 1. Geographic position of Slovenia in EU (Source: Author's archive)

Carrying capacity can be measured in a number of different ways, but in the development of Heritage Trails the major issues concerned the development of the local economy and the management of sites and whether or not

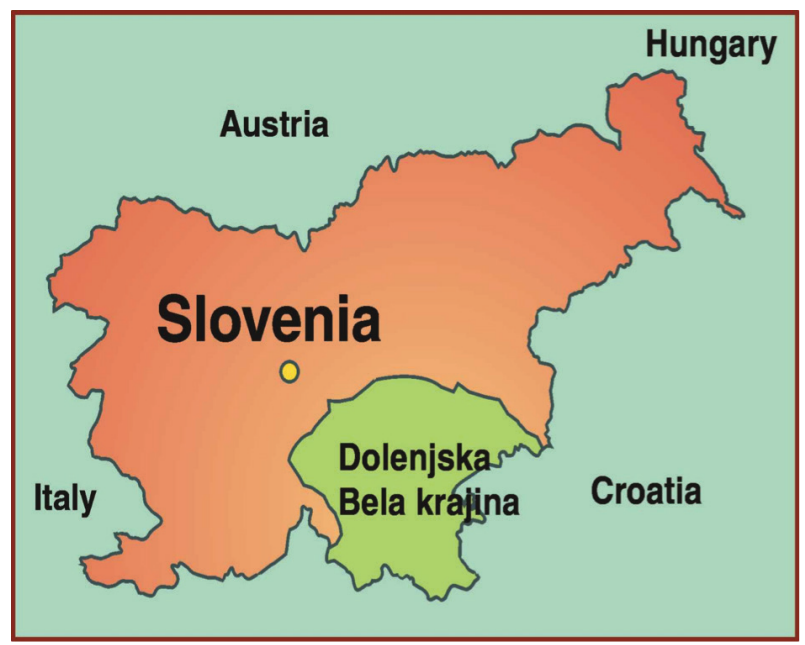

Figure 2. The region of Dolenjska and Bela krajina in Slovenia (Source: Author's archive)

particular sites should be excluded (on the grounds that the likely impact of additional visitors will be that of damage to the site or visitors being unwelcome to local people). 
Local people must be consulted in the assessment of landscapes and cultural and natural heritage assets. It is essential to ensure that the local impact of increased heritage tourism is brought within the process of developing and marketing tourism products.

\section{Origins and catalysts}

The thirty year period from 1960-1990, saw distinct phases of evolution in tourism, planning, conservationfocused thinking and actions in the Western World. This led to the concepts and processes of sustainable tourism planning. For example, in the UK, by the end of the 1980's a National Task Force on 'Tourism \&the Environment' had been established in order to provide sustainable tourism guidelines for three problem categories:
a. the Countryside
b. Heritage Sites
c. Historic Cities and Towns.

In the case of the Slovenia example explained in the case study, an additional factor is the multiple dynamic of international, national, regional and local agencies involved in the project. These were drawn from public, private and social sources, but the key actors and catalysts who can be identified in this story were the Slovenian Ministry of Agriculture, the Bavarian State Ministry for Agriculture, the Faculty of Architecture in Ljubljana, the European Commission's Tourism Directorate, a Regional Chamber of Commerce, a commercial tourism operator, and at later date, an international market research consultant.

\section{Integrated rural community development project}

The CRPOV Programme (Integrated Rural Development and Village Renovation), which commenced in 1990, was associated both with the UN Food \& Agriculture Organisation (FAO) and with the Bavarian Ministry for Agriculture. Bavaria helped in the initial phase transferring experience and know-how. CRPOV was based on a bottom-up approach, involving an initial 14 local project-areas, starting in 1991. Two of the project villages were located in the Slovene municipality of Trebnje with around 500 local residents involved in the project. During this period some 250 local projects were developed in Slovenia, primarily aimed at development possibilities for rural economic diversification (Koščak, 2002).

The community development role of CRPOV involved many local village meetings, linked to the economic need for diversification of the rural economy. CRPOV worked together with an expert team on strategy and action. Critically, this case-study relates to a rural region which sits strategically between Ljubljana and Zagreb, on the international motorway from Belgrade to Ljubljana. This has a high location potential for selling locally-sourced food and wine products, as well as craft and tourism products. Tourism is based on the appeal of a gentle landscape of hills and river-valleys - for walking, horse-back riding, cycling, angling, rafting, or the simple enjoyment of its unspoilt character! (Koščak, 2009).

The CRPOV, as an Integrated Rural Community Development programme, led the way towards rural product development, and as a by-product, communitybased sustainable tourism. Such tourism requires partnership and co-operation between the public, private and the NGO voluntary sectors. Co-operation of this sort was not common in the period 1992-1995 in Slovene tourism. It was clear, however, that sustainability - in Slovenia or anywhere else - requires community involvement together with the firm the commitment of local actors and producers of products and services. The appeal of such action is to add tourism products to the other rural products, which they complement (NB. Community-based rural development is thus an ideal starting point for sustainability, whether in agriculture, and /or in tourism. This creates an 'environment' in which new opportunities for economic diversification, new job-creation, added value to agricultural products, local guiding, and new farm-services can occur. In this process, institutions like an Agricultural Extension Service and others play a very important role, in terms of capacity-building, and of human resource development) (UNEP/ICLEI, 2003). 


\section{International team Heritage trail consultancy}

This background of the CRPOV programme, as well as the parallel development in terms of Wine Trails, prompted the Regional Chamber of Commerce of Dolenjska \& Bela krajina to accept an invitation by a consortium (which had in 1996 secured European Union funding to launch two pilot projects in Slovenia and Bulgaria) to create Heritage Trails. The consortium included Ecotourism Ltd. (a British consultancy firm), PRISMA (a Greek consultancy firm) and ECOVAST (The European Council for the Village and Small Town). All of these were supported by regional and national institutions in the field of natural and cultural heritage.

The UK/Slovene Heritage Trail team conducted a 'Tourist Resource Inventorisation \& selection', based upon natural, built and living cultural heritage resources in the selected region. Some 150 sites were identified and proposed by the different partners involved in the participation process for the Heritage Trail. From this large number, 28 sites were selected to be networked in a trail system for the area. The idea was to develop a tourist product which was capable of offering opportunities for stays of up to seven days in the region. Two key accessforms were used for the clustering of attractions, one a "flower structure", and the other a "garland structure". Existing tourist assets and potentials were the basis of these groupings (Koščak, 2009).

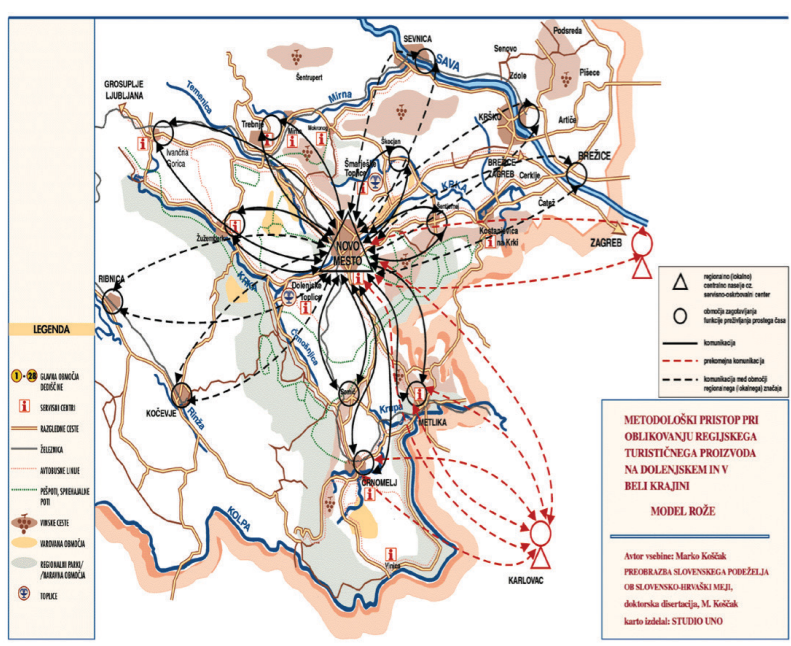

Figure 3. Flower model (Source: Author's archive)

A major result of this work was the creation of a Regional Partnership of 32 organisations, from the public, private and NGO sectors, which signed an agreement to co-operate in the Heritage Trail's implementation phases of marketing and product development. This partnership - working under the umbrella of the Regional Chamber of Commerce - was in operation for 12 years, and was in 2009 transformed into the LEADER Local Action Group - LAG responsible for overall rural development in the region of SE Slovenia, including sustainable tourism. The partnership supports, co-ordinates and brings together the provider-partners. Work in general consists of marketing activities, product development, and training activities, where different combinations of partners, institutions, and individuals are involved.

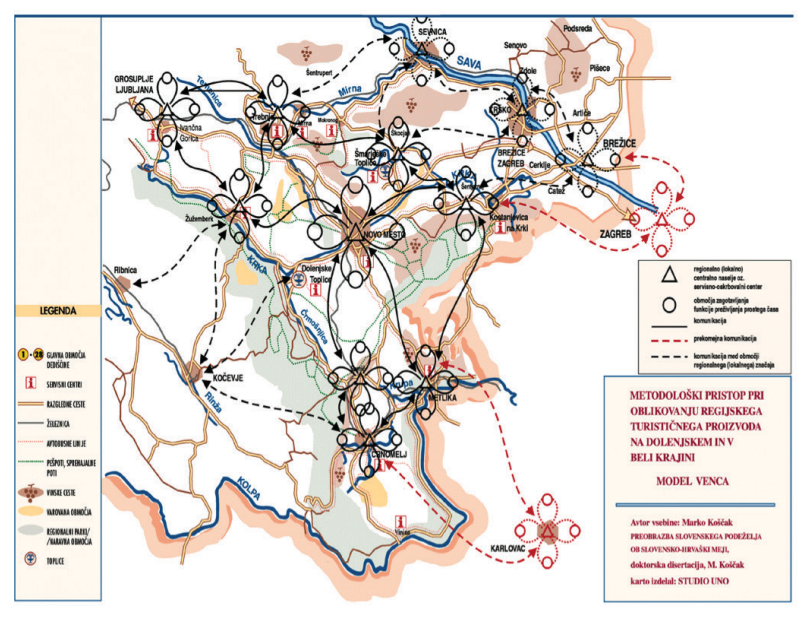

Figure 4. Garland model (Source: Author's archive)

For marketing purposes, a local commercial partner - Kompas Novo mesto - was invited into the partnership in 2001, in order to articulate a stronger and more effective assault on foreign markets. Kompas was engaged to act as the marketing agency, on behalf of the Heritage Trail partnership. Although the official launch of the product was in 1997, at the World Travel Market in London, followed in 1998 by a presentation at ITB/ Tourist Fair in Berlin, there was no significant response. Foreign markets at that time had limited awareness about any Slovene tourist products, other than what can be described as the constantly featured traditional Slovene Tourist icons such as Lake Bled, Kranjska Gora ski resort, Postojna Cave, and Portoroz seaside resort (Travis, 2003).

The effective commercial launch of the Heritage Trail at an international level, with a foreign tourist industry adviser and a much greater professionally co- 
ordinated national approach, was delayed until 2002, in London. There, at the World Travel Market, the launch had the active support of the Slovenian Tourism Board, together with other relevant institutions.

\section{Stages of commercial product adaptation and implementation}

Despite the launch of the Heritage Trail in the domestic market, followed by the international launch at the World Travel Market in 2002, the level of response by foreign tour-operators and travel agents was weak. It became clear that external help was required to target appropriate foreign tourism-trade partners, as well as to identify and select niche markets. From the market research on Slovenia's key foreign markets, the special interest markets, with a focus on either cultural tourism or nature-tourism (eco-tourism), were selected. Independent and some major commercial operators were to be approached by phone, fax, or on-line. 200 firms were identified in seven European countries; of these, 60 firms were contacted by at least two contact modes, but only six showed some degree of interest.

The problem revealed was that though there is much interest in Slovenia as a high-growth destination country, it was seen by the international industry as one with three major attractions - the 'tourism icons' already mentioned - lakes and mountains, caves and sea. For a significant period of time, Slovene overseas marketing has tended to focus only on these well-known destinations!

By 2003, low-cost airlines made Slovenia easily accessible to high-spending markets. Air travel cannot be a basis for sustainability, but may have to be used as the initial opening-up phase for a new destination or product in the first place. Ultimately connected railtravel access must be the longer term primary aim. However, as this initial stage of opening the Heritage Trail market, the transport access methodology was via the low-cost airline destination airports of Ljubljana (Easyjet), Klagenfurt (Ryanair) and Graz (Ryanair), with ground access transport routing via Ljubljana. In-depth contact with key operators by phone showed that there were two viable special-interest packages, which could appeal commercially (Travis, 2003):

a. A Heritage Trail Add-On Package to offers at Bled (Lakes \& Mountains) or Ljubljana (City \& Culture)

b. An Integrated new 'Highlights of Slovenia' holidays, which started with $25 \%$ of their time at two existing icons (Bled \& Ljubljana), then the remaining $75 \%$ of the time allocation spent on the Heritage Trail (Travel Manuals, 2003).

Testing of this product with a group of six UK travel professionals was extremely successful. A second tour with tour-operators from Germany and the UK in 2004,

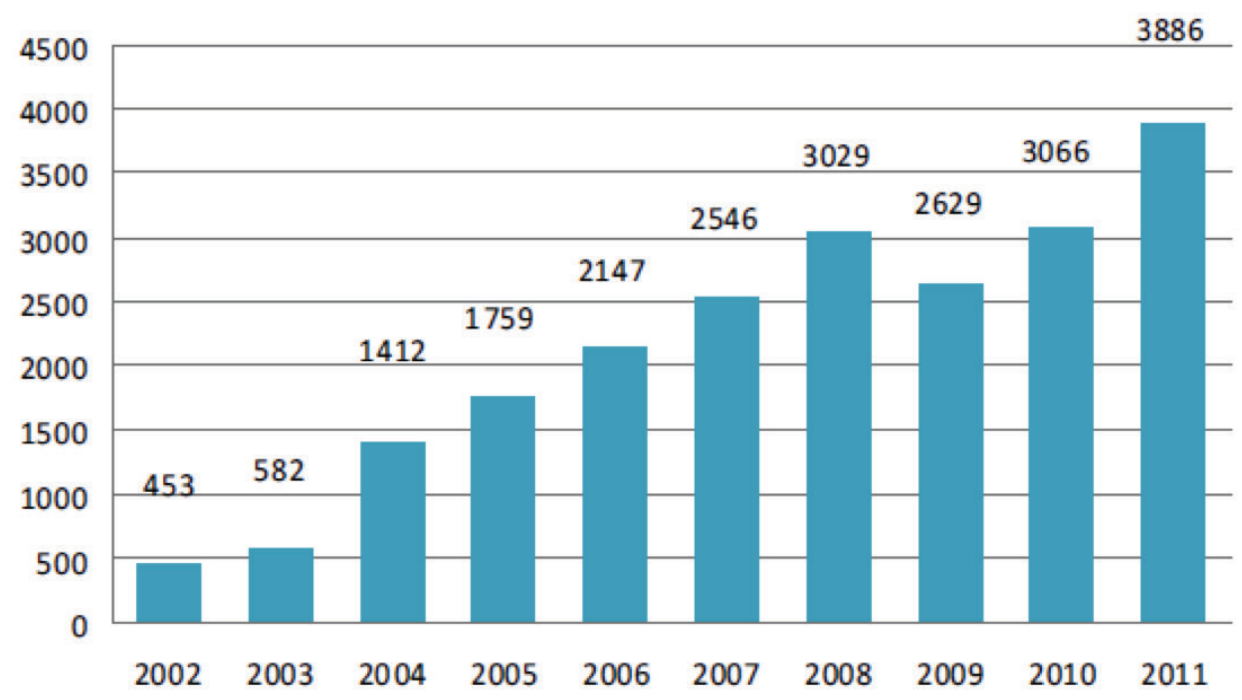

Figure 5. Volume of visits to Heritage Trails product from $2002-2011$ (Source: KOMPAS Novo mesto, 2012) 
was less successful. In 2005, a specialist walking-tour firm assembled its bespoke and individualised Heritage Trail offer, and, at the time of writing, Independent Tour Operator firms were preparing two individualised alternative packages for launching on-line.

\section{Heritage trails and creative industries in case of} Dolenjska and Bela krajina development

Already at a very early stage of HT development, a number of initiatives were taken in order to support and encourage the individual and private sectors to become important parts of this development. The major idea behind it was to create opportunities for new jobs and economic diversification in rural parts of Dolenjska and Bela krajina, in the SE region of Slovenia. With such initiatives and support of HT partnership in providing funding, some 600 individuals took different type of education and training, such as meat and milk processing, bakery, beekeeping, wine production and its marketing, tourist guiding, fruit drying in a traditional way, and many others. All these individuals received certificates that allow them to open their individual businesses and to satisfy all legislative requirements, on the one hand, and, on the other hand, to apply for further funding from Rural Development Programmes offered by the fact that Slovenia joins EU in 2004.

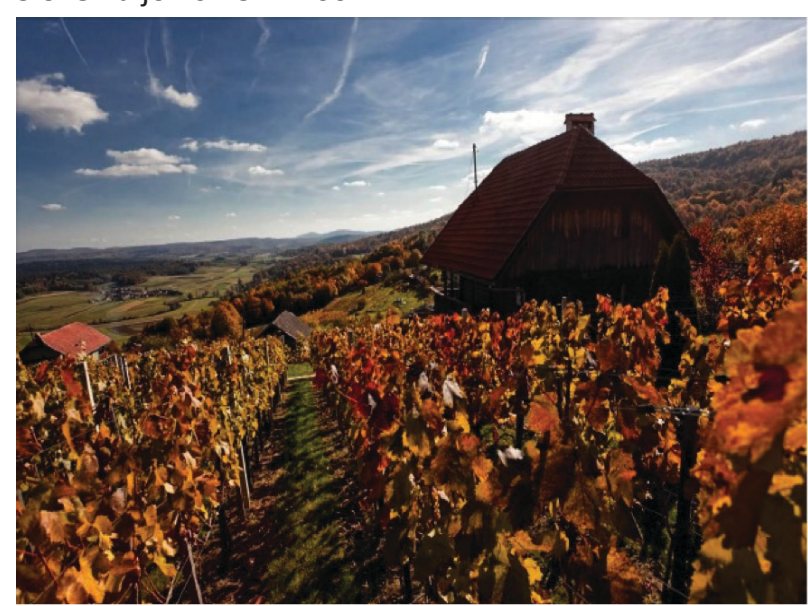

Figure 6. Vineyard retreats

(Source: Author's archive)

Different local thematic routes, such as wine, fruit, cheese and others were created where local entrepreneurs started to create new tourism products and through the marketing of HT partnership offer them on domestic and international markets. All above mentioned activities were conducted and implemented by HT partnership institutions, Chamber of Agriculture, which was responsible for the organisation of all trainings and certification based on the national curriculum for supplementary activities and Regional Development Agency which offers support and expertise in providing know-how on business plans and other entrepreneurial activities needed for application on tenders of various EU funding.

After this initial stage of certification, which was important in order to assure that business will operate on legal ground as well as according to new EU regulation and requirements, next stage of more innovative and robust initiatives were taken place. Some individuals and even group of partners decided to develop new product which has traditions back in past and give them fresh and new outlook as required on modern EU tourism markets (The Gallup organization, 2011).

Finally on many of new developments there are already guests which "brings" added value to rural economy of Dolenjska and Bela krajina. One of the best demanded and sold product is "vineyard retreats", which is basically renting traditional wine cellars to guest as selfcatering units. Nicely located buildings (Figure 6) and its offer present unique and unforgettably rich experience, both in terms of rural accommodation, traditional food (Figure 7) and opportunities for active holidays in rural SE Slovenia.

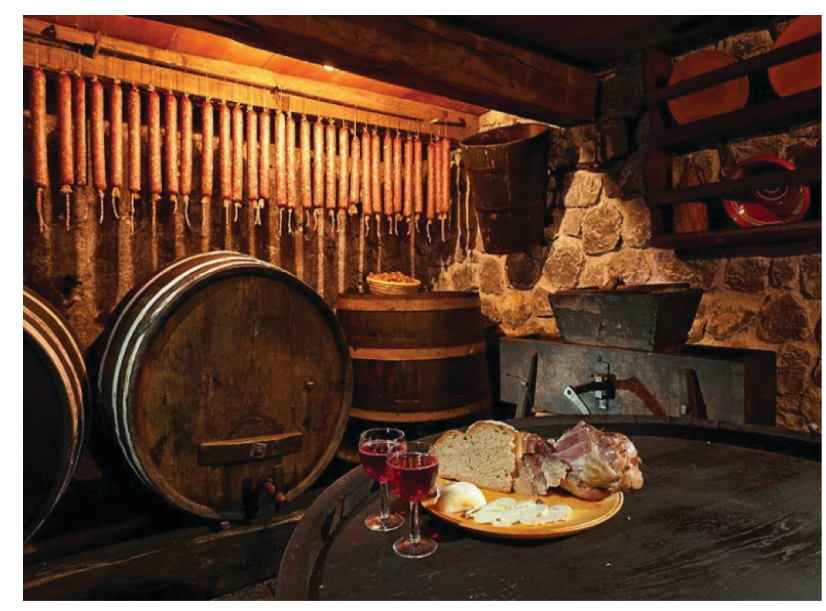

Figure 7. Vineyard retreats (Source: Author's archive) 


\section{Thematic routes - next stage development}

From these well-accepted beginnings we seek further development of the product. Our thinking was guided by the facts that:

- More than $75 \%$ of tourist from foreign markets are seeking for active holidays,

- More than $50 \%$ of reservations are made through the Internet,

- More tourists want to change destinations every couple of days, etc. (Koščak, 2012).

It was obvious that there is a need to create the product which:

- Can be used by individual traveller in the same manner as by tour operator;

- Will connect actual tourist offers in the region;

- Will be supported by all new common and used technologies;

- Will support active holidays;

- Should be different than other products in the field of active holidays.

In 2009 and with financial support of the European Regional fund, the abovementioned activities were successfully finished within the project, which fulfilled all those conditions. With the project the "back-bone" was built with four main activities, namely hiking, biking, horse riding and rowing in the whole region (Figure 8). The routes are connecting natural and cultural heritage of the region with other tourist offers, such as accommodation, activities, information, services, etc. (Koščak, 2012).

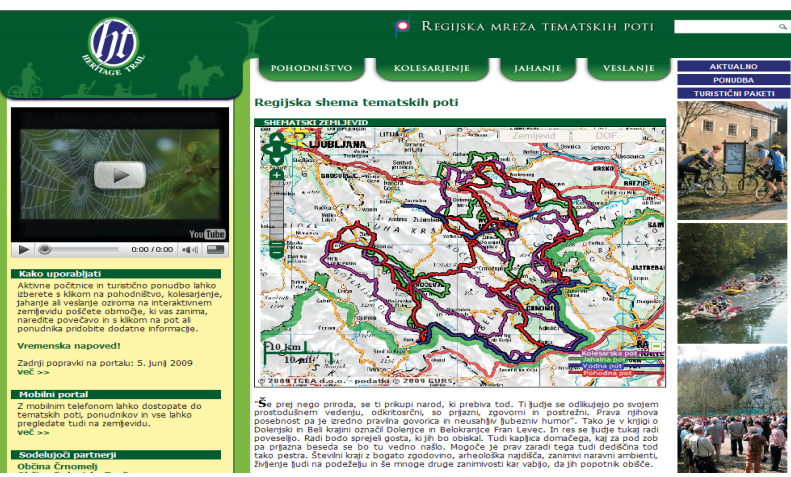

Figure 8. Regional thematic Routes (Source: http://www.slovenia-heritage.net/)
Wholly digitalised and located by GPS, routes are now presented in the renewed portal http://www. slovenia-heritage.net/ and the newly-built mobile portal http://activeslovenia.mobi. The product also is presented on Facebook and YouTube. Biking and horseback riding routs are also visualised. The potential tourist can detail look and plan its holidays from home (internet). Once in the field, they can use Mobile, PDA, GPS devices (and print-outs) to navigate the region. For those who do not have enough time to create holidays by themselves, the active tourist packages are (pre)-prepared and shown on the web as well.

\section{Learning points}

1. It is evident from the Case Study that the Heritage Recycling for Tourism phase was preceded by the work on Integrated Rural Community Development. This stimulated a community-based approach to development, in which context tourism was a part of the economic mix. This created a real hope of sustainability via the local communities support for a new mixed economy, thus indicating that sustainable development can underpin successful tourism, if the correct strategy is chosen.

2. The evidence from the project has also made clear that heritage-resource based tourism development, if it is to be sustainable, must a) show respect for the carrying capacity of resource-zones - be they robust or fragile and b) have rural community involvement and commitment to tourism, because they have a stake in it, and have net gains from it.

3. Much of tourism development arises because the destination creates potential tourism products, because they wish economic gain from them. Rural tourism products have to be adjusted to fit the (internationally highly competitive) niche market demands. Thus, market awareness and understanding must be built-in early in the development process, or it becomes much longer and harder.

4. New tourist destinations are very difficult to 
launch internationally, even if they have high accessibility, unless they can be linked and tied in to existing tourism icons or magnets. This new Slovene offer had to be adjusted to do just that.

5. The "gateway" identification is critical in new product formulation. Whether this be a selected airport, seaport, railway station or whatever. If the gateway is the airport of an attractive heritage city (such as Ljubljana), then both add-on package possibilities, as well as links to a popular 'short-city break' destination, add great value.

6. Continuity of personnel in a development process is of real importance. The role of the Project Manager in initiation and continuity is critical and the continuing interactions with external partners who are supportive and share a belief in the integrity of the development, over the long term - are also valuable.

7. This model, ultimately, is one of communitybased multiple-stakeholders, having the equal support of small rural operatives and major agencies. The support from several levels: local, regional, national, and international, has allowed the thirteen year development-cycle of the Dolenjska-Bela krajina HT project to be achieved.

\section{Conclusion: Critical Success Factors}

There are good reasons why the Slovene Heritage Trail model is being successfully adopted in several neighbouring countries as an initiative for rural regeneration through sustainable tourism, namely:

\section{Factor 1 - Economic regeneration}

A heritage trail is created as a tool for rural economic regeneration. The heritage trail extends tourism from existing centres into new and undervisited areas by increasing the number of visitors, extending their stay and diversifying the attractions and services offered to them: expansion, extension and diversification.
Factor 2 - Contributing to regional tourism development

The heritage trail is a tourism product which makes the natural and cultural heritage of a region the focal point of the offering. The development of such a product is, therefore, an integral component of the development of the whole region as a tourism destination. However, a heritage trail is only one product, and many regions have other tourism products on offer which may not be included in the trail. In creating heritage trails in Slovenia, there was frequently a temptation to include all tourism attractions and services in the region. But to give in to such a temptation would have been to lose the focus of a well-defined tourism product.

\section{Factor 3 - Complementing other tourism products}

Although a heritage trail focuses on only some of the attractions of a region, it can be complementary to other tourism products on offer. For example, it can contribute to economies of scale in regional promotion - in Slovenia, the heritage trail and spa tourism were promoted jointly, and costs of this shared. A heritage trail can also contribute to a wider choice of products for target markets. Taking the example of Slovenia again, spa tourists may be interested in the heritage trail product, and heritage trail tourists may enjoy the spa facilities.

\section{Factor 4 - Transferability}

The heritage trails concept is transferable to other regions and countries where there is sufficient natural and cultural heritage to attract tourists and where there is a local desire both to benefit from tourism and to safeguard that heritage. This is particularly the case in parts of central and eastern Europe where established settlement patterns and rural economies have developed similarly to those in Slovenia.

\section{Factor 5 - Sustainable tourism}

A heritage trail focuses on the natural and cultural assets of a rural region. This runs the risk of exposing some of the most vulnerable sites in a region to excessive numbers of tourists. The preparation of a heritage trail, therefore, must include a tourism "carrying capacity study" at each proposed tourism site. If a sudden increase in tourists risked damaging the physical or 
natural attributes of a site, or if it were to exceed the tolerance of the local people, it should not be included in the heritage trail until preventive measures can be implemented.

\section{REFERENCES}

European Parliament. (2007). Resolution of 29 November 2007 (Commission recommendation 2006/2129-INI) on a renewed EU Tourism Policy: Towards a stronger partnership for European Tourism: The European Parliament.

Jones, A., \& Travis, A. (1983). Cultural Tourism: Toward a European Charter: Report to WTB, EW Tourism Consultancy, Birmingham, UK.

KOMPAS Novo mesto. (2012). Unpublished statistical data. Novo mesto.

Koščak, M. (2002). Heritage Trails: Rural regeneration through sustainable tourism in Dolenjska and Bela krajina - Rast, XIII, 2(80), 204-211, MO Novo mesto.

Koščak, M. (2009). Transformation of rural areas along SloveneCroatian border. Unpublished doctoral dissertation. University of Ljubljana, Faculty of Art, Department of Geography.

Koščak, M. (2012). Po poteh dediščine - od teorije k praksi, Priročnik za načrtovanje trajnostnega razvoja in turizma z vključevanjem naravne in kulturne dediščine s praktičnimi primeri. STUDIO MKA d.o.o.

Malinowski, B. (1931). Culture. 4, 621 - 645 in Encyclopedia of the Social Sciences. New York: Macmillan.

Mathieson, A., \& Wall. G., (1982). Tourism: Economic, Physical and Social Impacts. Longman Group Limited, Longman House, Burnt Mill, Harlow, Essex, UK, 1982. 208p.

Po poteh dediščine. (s.a.). Localised April 2014 on http://activeslovenia. mobi.

Po poteh dediščine. (s.a.). Localised April 2014 on http://www. slovenia-heritage.net/

The Gallup organization. (2011). Survey on the attitudes of Europeans towards tourism. European Commission. Flash Barometer 328.

Travel Manuals. (2003). Heritage Trails through Dolenjska \& Bela krajina in Slovenia. Chamber of Commerce Novo mesto, 2003.

Travis, S.T. (2003). Market research on Slovenia's key foreign markets. Dolenjska \& Bela krajina marketing association, Chamber of Commerce Dolenjska \& Bela krajina.

Tylor, E.B. (1871). Primitive culture: Researches into the Development Mythology. Reprint 1958 New York: Harper Collins.
UNEP/ICLEI. (2003). Tourism \& Local Agenda 21 - Role of Loca Authorities in Sustainable Tourism. United Nations Environmental Program, Paris, France. The International Council for Local Environmental Initiatives, Freiburg Germany. UN Publication.pdf;

Datum prijave rada: 17.03.2016.

Datum prihvatanja rada: 19.05.2016.

\section{Kontakt}

Marko Koščak, Faculty of Tourism,

Cesta prvih borcev 36, Brežice, Slovenia

E-mail: marko.koscak@um.si 